\title{
Survival, growth and gonad development of two hermatypic corals subjected to in situ fish-farm nutrient enrichment
}

\author{
Lucia Bongiorni ${ }^{1}$, Shai Shafir ${ }^{1}$, Dror Angel ${ }^{2}$, Baruch Rinkevich ${ }^{1, *}$ \\ ${ }^{1}$ Israel Oceanographic and Limnological Research, National Institute of Oceanography, POB 8030, Haifa 31080, Israel \\ ${ }^{2}$ National Center for Mariculture, POB 1212, Eilat 88112, Israel
}

\begin{abstract}
Nutrient enrichment in oligotrophic tropical waters is considered one of the main causes for coral reef degradation. In the present study, the impacts of net-pen fish-farming in the Gulf of Eilat, Red Sea, on coral biology were evaluated by investigating survival, growth and gonad development in 2 common branching coral species. From 10 Acropora eurystoma genotypes (colonies) 200 branches were collected and suspended for 7 mo from PVC plates adjacent to a commercial fish farm. They grew 3 times faster than a similar set of branches taken from the same 10 colonies and suspended on PVC plates at a non-enriched reference site. The increase in branch weight and volume was 2.7 and 4.3 times greater, respectively, at the fish farm than at the reference site. Survival rates were $100 \%$ at both sites. Nubbins of Stylophora pistillata deployed on plates at the 2 sites initially (first $4 \mathrm{mo}$ ) grew more rapidly at the reference site, but after $13 \mathrm{mo}$, the vertical extension levels were significantly larger at the fish-farm site $(19.2 \pm 6.1 \mathrm{vs} 16.3 \pm 4.6 \mathrm{~mm}$, respectively). The average number of oocytes polyp ${ }^{-1}$ and the number of polyps with developing testes in mature $S$. pistillata colonies were significantly higher at the fish farm than at the reference site. It is suggested that nutrients released from intensive mariculture may not necessarily lead to the demise of coral reefs, as is commonly presumed.
\end{abstract}

KEY WORDS: Acropora $\cdot$ Coral growth $\cdot$ Eilat $\cdot$ Nutrient enrichment $\cdot$ Reproduction $\cdot$ Stylophora pistillata

Resale or republication not permitted without written consent of the publisher

\section{INTRODUCTION}

Nutrient enrichment (either particulate or dissolved) is considered one of the main causes for environmental decline in oligotrophic waters harbouring coral reefs (Smith et al. 1981, Pastorok \& Bilyard 1985, Wittenberg \& Hunte 1992, Hunter \& Evans 1995, Lapointe 1997, Roberts et al. 2002; and literature therein). High levels of nutrients stimulate macroalgal growth (Lapointe 1997) enabling the macroalgae to rapidly cover living coral tissues. High nutrient loads also lead to an increase in phytoplankton biomass, resulting in turbidity and reduced submarine light levels which affect zooxanthellae photosynthesis (see literature cited in Naim 1993, Genin et al. 1995, Dubinsky \& Stambler 1996, Koop et al. 2001). Additionally, fast growth of filter-feeding invertebrates such as bryozoans, sponges and tunicates may out-compete corals for substrata, resulting in a corresponding decrease in the diversity and abundance of hermatypic corals.

Many of the direct impacts of nutrient enrichment on the biology of corals are less clear, mainly because the above indirect effects may obscure the corals' physiological and biochemical responses. Laboratory analyses indicated that nutrient enrichment leads to increased zooxanthellae abundance and chlorophyll a content in coral tissue (Hoegh-Guldberg \& Smith 1989, Stambler et al. 1991, 1994, Muller-Parker et al. 1994, Snidvongs \& Kinzie 1994) and reduced coral growth and calcification rate (Kinsey \& Davies 1979, Tomascik \& Sander 1985, Davies 1990, Tomascik 1990, Stambler et al. 1991, Stimson 1992, Marubini \& Atkinson 1999). Koop et al. (2001) found that the outcome of nutrient enrichment ( $\mathrm{N}$ and $\mathrm{P}$ ) depends on nutrient-dose levels 
and on the coral species studied. An assessment of the variables used to evaluate coral health suggests that reproductive success (Tomascik \& Sander 1987, Harrison \& Ward 2001, Koop et al. 2001), growth and calcification rates (Hoegh-Guldberg et al. 1997, Steven \& Broadbent 1997, Marubini \& Atkinson 1999, FerrierPagès et al. 2000) are sensitive indicators of nutrient enrichment impacts. However, the scientific literature on nutrient enrichment contains contradictory reports regarding the effects of nutrients on hermatypic corals. For example, Atkinson et al. (1995) recorded high growth rates among 57 species of corals growing in high-nutrient seawater in the Waikiki Aquarium, Hawaii. Similar results were reported for several nutrient enrichment experiments carried out on corals in their natural environment (Grigg 1995, HoeghGuldberg et al. 1997, Steven \& Broadbent 1997). Meyer \& Shultz (1985b) and Lieberman et al. (1995) documented enhancements in skeletal deposition, tissue growth rates and reproductive efforts in branching corals harbouring schooling fishes that provide a continuous supply of nutrients to the corals via fish excreta.

Intensive net-pen fish-farming, a rapidly expanding industry throughout many of the world's coastal regions, is known to release large quantities of dissolved and particulate matter to the surrounding waters (Brown et al. 1987, Beveridge 1996, Karakassis 2001). Pitta et al. (1999) showed that warm-water fish farms discharge dissolved and particulate nutrients to the surrounding environment throughout the year. If we accept the view that nutrient enrichment is detrimental to coral health, the recruitment, growth and survival rate of corals in the vicinity of fish farms

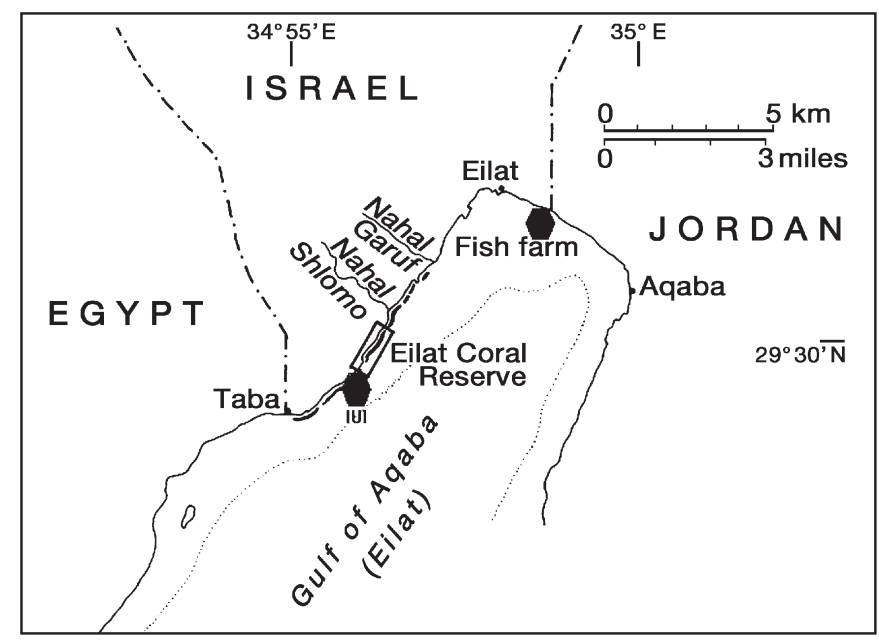

Fig. 1. Map of study sites in Gulf of Eilat (Aqaba), Red Sea. Hexagons indicate Ardag fish farm at northern end of the Gulf and Inter-University Institute (IUI) control site along the southern part of Eilat's shore should be inferior to those of corals in oligotrophic waters. The rapid and continuous deterioration of the coral reef at Eilat (Epstein et al. 1999, 2001) and the nutrient and particle loads generated by the fish farms (D. Angel et al. unpubl. data) evoke increasing concern (Mancy 1993) and debate regarding the environmental impacts of cage aquaculture on the coral reef. Despite these concerns, detailed studies that critically evaluate this topic have not been undertaken.

In this study we have assessed the impacts of a commercial fish farm near Eilat, Israel, on some life-history parameters of selected coral species. For this purpose, transplanted and resident coral colonies adjacent (10 to $20 \mathrm{~m}$ ) to the fish cages were compared to transplanted and resident colonies situated at a nearby relatively clean (reference) site. Two branching coral species, Acropora eurystoma (Klunzinger 1879: cited in Wallace 1999) and Stylophora pistillata, commonly found in the coral reefs of Eilat (Loya 1972), were chosen. Survival rates, growth rates, reproductive activity and lipid storage levels were used as indicators of nutrient enrichment impacts.

\section{MATERIALS AND METHODS}

Study sites. The Ardag fish farm $\left(29^{\circ} 32.45^{\prime} \mathrm{N}\right.$, $34^{\circ} 58.40^{\prime} \mathrm{E}$ ) is situated on the north shore of the Gulf of Eilat (Aqaba), Red Sea (Fig. 1) over a sandy seafloor. The net cages of this commercial farm (established in 1988) are stocked mainly with gilthead seabream Sparus aurata. The farm consists of 3 parallel pontoons that support the fish cages. During 2001, the annual estimated discharge from the production in the central and western pontoons (both particulate and dissolved forms: calculated from Lupatsch \& Kissil 1998) of the Ardag farm consisted of 92 tons nitrogen and 16 tons of phosphorus.

The Ardag farm is located south of Nahal Arava, a dry riverbed that episodically (following winter rains) conveys large quantities of fine alluvial material to the Gulf of Eilat. The amount of terrigenous unconsolidated sediment deposited in the area can suffocate or bury settled coral colonies. Thus, coral colonies are found in this region only on elevated hard substrata, mostly on artificial objects (ropes, concrete sinkers, automobile tires, etc.). Despite the high sedimentation and the potential harmful effects of the fish cages, the presence of $>450$ coral colonies representing at least 22 different genera was recorded during 2000 within a lateral distance of $30 \mathrm{~m}$ from the fish cages (D. Angel et al. unpubl. data). In 2001, the monthly average nutrient levels at the fish farm were $0.095 \mu \mathrm{M}$ for nitrite, $0.385 \mu \mathrm{M}$ for nitrate, $0.123 \mu \mathrm{M}$ for orthophosphate and $1.016 \mu \mathrm{M}$ for ammonia (I. David, B. Lazan \& A. Post unpubl. data). 
The coral reef in front of the Inter-University Institute (IUI) of Eilat served as the reference site in this study. It is located $8 \mathrm{~km}$ southwest of the Ardag fish farm and adjacent to the Eilat coral reef nature reserve (Epstein et al. 1999). The reef has a low-profile fringing structure, dominated by hermatypic coral colonies and associated invertebrates (Yahel et al. 1998). In 2001, the monthly average nutrient levels at the IUI site were $0.075 \mu \mathrm{M}$ for nitrite, $0.264 \mu \mathrm{M}$ for nitrate, $0.045 \mu \mathrm{M}$ for orthophosphate and $0.057 \mu \mathrm{M}$ for ammonia (I. David, B. Lazar \& A. Post unpubl. data).

Flux of particulate matter. The vertical flux of particulate matter was measured at the 2 study sites on 3 dates: 20 August 2001, 22 October 2001, and 31 January 2002. Sediment traps consisting of 4 PVC cylinders (5.6 cm in diameter, $70 \mathrm{~cm}$ in length) with collecting cups (Angel et al. 1995) were deployed at $6 \mathrm{~m}$ depths for $48 \mathrm{~h}$ on each of the sampling dates. Particulate samples collected in the cups were concentrated onto $47 \mathrm{~mm}$ diameter Whatman GF-C filters, rinsed with distilled water to eliminate salts, dried at $70^{\circ} \mathrm{C}$ for $24 \mathrm{~h}$, and weighed to determine dry weight (DW). The filters were then placed in a muffle furnace at $550^{\circ} \mathrm{C}$ for $8 \mathrm{~h}$ and subsequently weighed to determine ash-free dry weight (AFDW). The difference between DW and AFDW was attributed to combustible organic matter.

Coral growth. We collected 10 colonies of Acropora eurystoma (ca. 15 to $20 \mathrm{~cm}$ diameter) were collected from the north beach of Eilat during February 2001; these were stained for $24 \mathrm{~h}$ in situ with the vital stain Alizarin Red-S (10 $\mathrm{mg} \mathrm{l}^{-1}$ ) inside transparent plastic bags. The corals were left in their natal site for a $5 \mathrm{~d}$ post-labelling period. Subsequently, 40 branches (ca. $3 \mathrm{~cm}$ each) were removed from each of the stained colonies (400 branches altogether), split equally into 2 groups of branches, and attached in an upright, vertical orientation to PVC plates by means of plastic clothes-pegs. The first set of 4 plates, each carrying 5 replicates of each coral colony (a total of 200 Alizarinstained branches), were moored adjacent to the western pontoon of the Ardag fish farm (10 to $20 \mathrm{~m}$ from the fish cages) at $6 \mathrm{~m}$ depth (seafloor depth at that site is $22 \mathrm{~m}$, i.e. we excluded possible impacts from resuspended bottom sediments). The plates with attached branches were situated between the western and central pontoons of the farm, thereby ensuring maximal exposure to fish-farm effluents, regardless of the direction of prevailing currents (Brenner et al. 2001). The second set of 4 plates (with 200 stained coral branches) was moored at $6 \mathrm{~m}$ depth at the IUI site (seafloor depth at this site was 10 to $11 \mathrm{~m}$ ). During the experiment, algae and encrusting invertebrates were removed from the PVC plates on a monthly basis. The PVC plates were recovered 7 mo later, in October 2001; the branches were removed and examined to determine survivorship and growth at each site. Coral tissue was separated from the calcareous skeleton by $2 \mathrm{~d}$ immersion in a chlorine solution. Coral skeletons were dried, weighed $( \pm 0.01 \mathrm{~g}$ accuracy), cut at the level of the Alizarin line with a side cutter to separate the postlabelling deposited skeleton, and weighed again. Each coral branch was photographed with a scale before and after removal of the newly deposited skeleton: 2 sets of photographs, 1 of the branch's lateral side and 1 of its upper surfaces were taken before and after skeleton removal. The photographs were digitized and analyzed with the image-analysis software TINA 2.07 to obtain height $(h)$, width $(w)$ and length $(l)$ of each branch (Loya 1976). An 'ecological volume' index was established for each branch by assuming a cylinder shape with volume $V=\pi \mathrm{r}^{2} \times h$, in which $\mathrm{r}=1+w / 4$ (Rinkevich \& Loya 1983). This 'ecological volume' represents the water volume occupied between the branches of the developing ramet.

In an additional set of experiments, coral nubbins (very small fragments of a colony, consisting of only a few polyps: Shafir et al. 2001) were taken during April 2001 from 6 Stylophora pistillata colonies using a fine side-cutter. Nubbins were sampled from 3 colonies from the north beach of Eilat and 3 from the IUI site. The advantage of using nubbins is that a large number of genetically identical replicates can be obtained from a single coral branch, therefore causing minimal stress to the donor colony (Davies 1995, Shafir et al. 2001). The exposed skeleton surfaces of the freshly cut nubbins were dried and glued with a drop of cyanoacrylate glue (SuperGlue) to PVC plates. The plates were then transferred to a small platform moored at $6 \mathrm{~m}$ depth. Trauma was minimized by limiting air exposure to a few minutes and by rinsing each nubbin with fresh seawater upon isolation. At each of the 2 experimental sites, 190 nubbins were glued onto 3 PVC plates. Nubbins were photographed at the beginning of the experiments and after 3, 4 and 13 mo. Photographs were analyzed by the image-analysis package TINA 2.07. Survival rates and the percentages of nubbins that spread (laterally on the plates) were recorded, while nubbins growth rates were assessed from the lateral expansion of coral tissue, as typically reported for this species (Shafir et al. 2001).

Reproductive activities. To assess coral gonad development, we chose 14 colonies of Stylophora pistillata (>10 $\mathrm{cm}$ in diameter) growing naturally at 10 to $17 \mathrm{~m}$ depth on artificial substrata near the Ardag fish cages (<50 m distance). At the IUI control site, 14 similar-sized S. pistillata colonies, located in the same depth range, were selected. Single-branch samples, representing the reproductive activity of the colonies (Rinkevich \& Loya 1979), were taken from each colony in January, May and December 2001 (these months 
cover 2 phases in the coral's reproductive cycle). Branches were transported to the laboratory in seawater in plastic bags, and were immersed in 50\% seawater-Bouin's fixative solution for a period of $2 \mathrm{wk}$. Following this, a $5 \mathrm{~mm}$ tissue sample was removed from each of the decalcified branches and prepared for histological examination (Rinkevich \& Loya 1979). The paraffin-embedded tissue was sectioned (5 to $6 \mu \mathrm{m}$ thick sections), mounted on glass slides, and stained with eosin and haematoxylin. For each sample, 8 to 10 polyps were examined in serial sections to determine presence of male gonads and numbers of female oocytes per polyp, stage of gametogenesis and oocyte size (sensu Ward \& Harrison 2000).

Lipids in coral tissue. At the end of the coral growth experiment ( 7 mo under local ambient conditions), 3 fragment replicates, 2 to $3 \mathrm{~cm}$ each, were sampled from 8 randomly chosen ramets of Acropora eurystoma per site. In addition, fragments were sampled from 12 of the resident Stylophora pistillata colonies that were studied for reproductive activities, at each of the study sites. Fragments were sampled randomly. All samples were placed in $10 \%$ formaldehyde-seawater solution for $24 \mathrm{~h}$, rinsed with distilled water, and extracted in chloroform: methanol (2:1) for $24 \mathrm{~h}$ (Harriott 1993). The extracts were evaporated at $60^{\circ} \mathrm{C}$ and weighed to the nearest $\pm 0.0001 \mathrm{~g}$. The remaining coral branches were decalcified in $10 \% \mathrm{HCl}$, dried at $60^{\circ} \mathrm{C}$, and weighed. Lipid content was calculated as the weight of lipid extract/(weight of lipid extract + tissue weight) $\times 100 \%$. The lipid content of each colony was calculated as the average of 3 replicates.

Statistical analyses. All statistical tests were performed using SPSS 8.0 (SPSS 1989-1997) and SAS (SAS Institute 1999) statistical packages. The assumption of normality and homogeneity of variance were tested by Kolmogorov-Smirnov and Levene's statistical tests, respectively. Post hoc multiple comparisons of means were carried out by Tukey's HSD test. When required, data was ln transformed. The non-parametric Mann-Whitney $U$-test was employed where results did not show a normal distribution pattern. Results are presented as average \pm SD except where indicated.

\section{RESULTS}

\section{Particulate matter flux rates}

Flux rates of total particulate matter and particulate organic matter on the 3 sampling dates were 5-, 6- and 2-fold higher and 10-, 13- and 7-fold higher, respectively, at the fish-farm site than at the IUI site (Table 1). The organic component of the particulate matter was $>44 \%$ at the fish-farm site and $<24 \%$ at IUI.

\section{Survival and growth rates}

The survival rates of Acropora eurystoma branches at both sites were $100 \%$ throughout the 7 mo that branches were maintained on the plates. There was no significant difference in the initial branch size between the 2 sites (Duncan's multiple-range test, $\mathrm{p}>0.05$ ). However, after 7 mo the branches at the fish-farm site had increased 3-fold in weight and linear extension and 4-fold in ecological volume compared to the branches at the IUI site (2-way ANOVA, p $<0.001$; Table 2). At the end of the experiment, branches growing at the fish farm had developed into small bushyshape colonies with lateral branches compared to limited development among branches at the IUI site (Fig. 2A). Despite the high variability among different colonies, both linear extensions of the branches and weight increases were significantly higher at the fishfarm site $(p<0.001$ and $p<0.05$, respectively; nested ANOVA). These site-specific differences were consistent among all 10 coral genotypes (10 different colonies) that were the source of the living coral tissue in the experiment.

We concentrated on nubbin survival and nubbin lateral growth rates on substrata in our studies on nub-

Table 2. Acropora eurystoma. Criteria for the estimation of branch growth rates at Ardag fish farm and IUI sites after 7 mo growth on PVC plates in the sea

\begin{tabular}{|lcc|}
\hline Criterion tested & Fish farm & IUI \\
\hline Weight increase $(\mathrm{g})$ & $10.4 \pm 6.1$ & $3.8 \pm 2.8$ \\
Linear extension increase $(\mathrm{mm})$ & $30.8 \pm 8.7$ & $9.6 \pm 5.3$ \\
Ecological volume increase $\left(\mathrm{cm}^{3}\right)$ & $211 \pm 160$ & $49 \pm 45$ \\
\hline
\end{tabular}




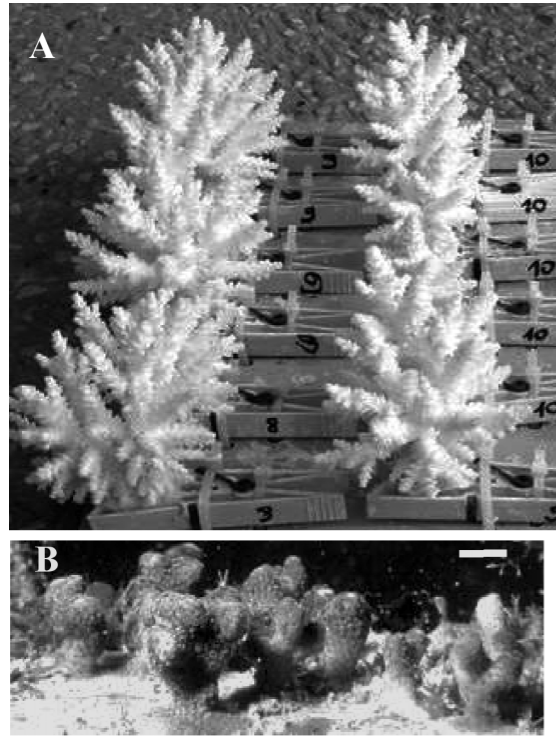

Fish Farm

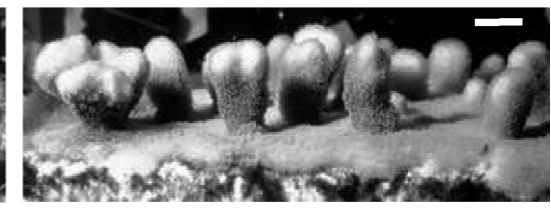

IUI-Reference site

Fig. 2. Acropora eurystoma and Stylophora pistillata. Growth of branching coral species. (A) Representative subset of branches from A. eurystoma after 7 mo on plates at the fish farm (left) and IUI (right); (B) linear extension of representative $S$. pistillata colonies grown from nubbins over a period of $395 \mathrm{~d}$ at the fish farm (left) and IUI (right). Scale bars $=1 \mathrm{~cm}$

bins. Lateral growth (spreading) of the Stylophora pistillata nubbins was observed $44 \mathrm{~d}$ after the beginning of the experiment. There was deposition and accumulation of particulate matter on the plates around the nubbins, occasionally even partially covering the nubbins. This phenomenon was more pronounced at the fish-farm site. While nubbin survival rates at the 2 study sites after 3 and 4 mo were not different, the number of nubbins that spread on substrata and their lateral growth rates were higher at the IUI site (Table 3; p $<0.001,2$-way ANOVA). However, the average growth rate of nubbins at the fish-farm site increased with time and doubled between the third and the fourth month of the experiment, whereas it taken from $28 \mathrm{~S}$. pistillata colonies (269 polyps in January 2001, 216 in May 2001 and 216 in December 2001). The number of colonies with female gonads was higher at the fish farm than at IUI in both January 2001 (93 vs $71 \%$ ) and May 2001 (100 vs $67 \%$ ). In December 2001, all colonies at both sites developed ovaries. The oocytes in the $S$. pistillata colonies growing near the fish farm were twice as large as their counterparts at IUI (52 $\pm 27 \mu \mathrm{m}$ diameter vs $26 \pm 23 \mu \mathrm{m}$, respectively), although the difference was not statistically significant. The average number of oocytes polyp ${ }^{-1}$ (Fig. 3A) was significantly higher at the fish farm than at IUI, and varied significantly between the 3 sampling dates (2-way ANOVA, $\mathrm{p}<0.01$ and $\mathrm{p}<0.05$, respectively). At the IUI site the second reproductive season was characterized by a significant higher number of oocytes polyp ${ }^{-1}$ than the first season (Tukey's HSD post hoc test). The proportion of colonies with developing male gonads in both January and May 2001 was higher at the fish farm than at IUI (93 vs $78 \%$ and 83 vs $33 \%$, respectively); it was even higher although not significantly different at the 2 sites in December 2001. The percentage of polyps with developing testes was significantly higher at the fish 

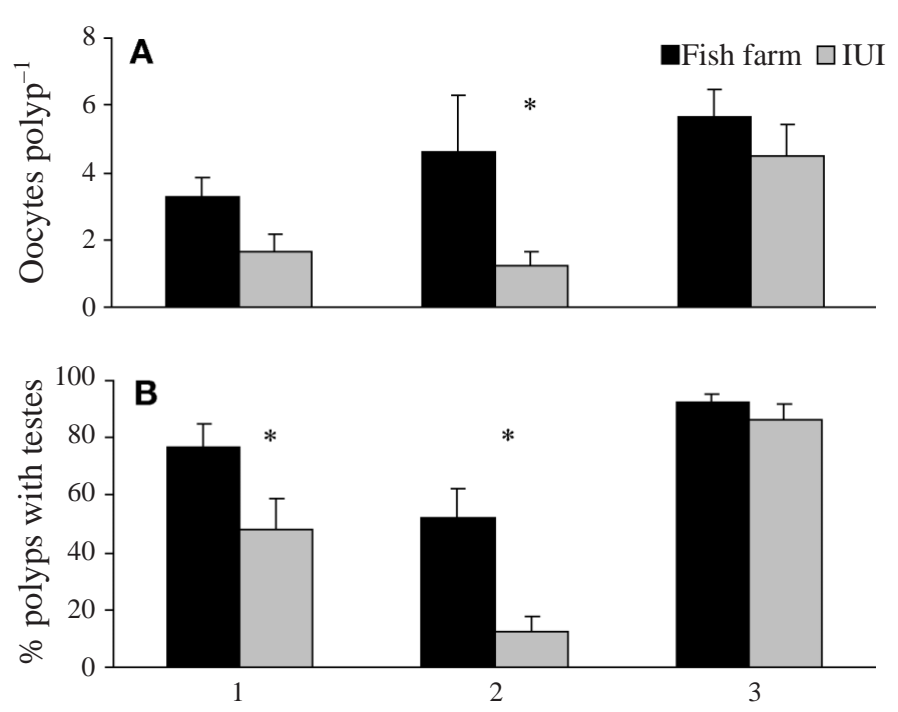

Fig. 3. Stylophora pistillata. Reproductive activities of mature ( $>10 \mathrm{~cm}$ in diameter) colonies growing at 10 to $17 \mathrm{~m}$ depth at the 2 study sites. (A) Average number of oocytes polyp ${ }^{-1}$ at the fish farm (black bars) and at IUI (gray bars); (B) percentage of polyps developing male gonads at the fish farm and at IUI.

SEs are also shown. $*$ Significant difference $(p<0.05)$

farm than at IUI throughout 2001 (74 vs 49\%, 2-way ANOVA, p < 0.001, Fig. 3B). There was an increase in the proportion of polyps with ripe testes (containing developed spermatozoa) during 2001 at the IUI, from 7 to $33 \%$, compared to a steady high value of $53 \%$ at the fish farm. At both sites, the highest percentage of gonads containing spermatozoa was recorded in the following reproductive season, 83.3 and $100 \%$, respectively.

\section{Lipid contents}

There was no significant difference in the lipid contents of Acropora eurystoma branches at the 2 study sites following the 7 mo in situ experiment (mean \pm SD $=42 \pm 9$ at IUI vs $38 \% \pm 5$ at the fish farm, $\mathrm{n}=8$ ). However, the average lipid content in tissues of naturally growing Stylophora pistillata colonies sampled at IUI was higher than at the fish farm $(36 \pm 5$ vs $30 \pm 3 \%$, respectively; Wilcoxon signed-rank test, $\mathrm{n}=12$, $\mathrm{p}<0.05$ ).

\section{DISCUSSION}

An abundant body of literature (reviewed by Beveridge 1996 and Black 2001), as well as local recent studies (Angel et al. 1998, Katz et al. 2002, I. David, B. Lazan \& A. Post unpubl. data) have shown that intensive net-pen mariculture releases substantial amounts of both particulate and dissolved forms of nutrients to the surrounding waters. As higher levels of nutrients have often been reported to negatively affect coral health, it was intriguing to discover that both Acropora eurystoma branches and Stylophora pistillata nubbins grew faster at the more 'eutrophic' fish farm than at the oligotrophic IUI site (the results obtained here may not reflect, however, longer-term, cumulative impacts of eutrophication: see literature cited by Dubinsky \& Stambler 1996). A similar situation was observed with the increased 'ecological volume' of developing branches that reflect actual water volume occupied between the branches of each colony. Moreover, the survival rates of coral branches and nubbins of both coral species were high and not significantly different between the 2 study sites. Although past studies have suggested a trade-off between coral growth and reproductive effort (reviewed by Rinkevich 1996), the results of the present study do not support this, since not only growth but also the reproductive activities of S. pistillata were higher at the fish farm than at IUI. These results seem to contradict studies that documented detrimental impacts of eutrophication on corals. Ward \& Harrison (2000) reported a significant drop in production of oocytes and planula larvae among $A$. longicyatus and $A$. aspera colonies subjected to nutrient enrichments in the ENCORE experiment (Great Barrier Reef). Similar results were reported by Tomascik \& Sander (1987) for Porites porites in the Caribbean. Our results also indicate that while higher growth rates and reproductive efforts were recorded at the fish farm (both are energy-demanding physiological parameters: Rinkevich 1996), the lipid contents in tissues of naturally grown $S$. pistillata colonies at the reference site (IUI) were significantly higher than at the enriched fish-farm site. It is possible that higher physiological-biochemical levels are associated with environmental conditions at the fish farm.

This observation leads to the question: do fish-farm nutrient effluents constitute an alternative or supplementary source of coral nutrition?

Although higher levels of nutrients are generally associated with detrimental impacts on coral growth and reproduction, Ferriér-Pages et al. (2000) suggested that the outcome of nutrient enrichment actually depends on the chemical form and concentration of these nutrients. It is well known, for example, that corals readily take up ammonium (Muscatine \& D'Elia 1978, Grover et al. 2002) and phosphorus (D'Elia 1977). In some studies, it was proposed that organic matter might provide corals with an additional food source in hyper-oligotrophic waters (Hoegh-Guldberg et al. 1997, Anthony 1999, Anthony \& Fabricius 2000). Meyer \& Shultz (1985a,b) and Lieberman et al. (1995) suggested that fishes living in close association with branching corals may enhance coral skeleton, tissue 
and reproductive growth by providing nutrients via fish excretion and faeces.

A large in situ multidisciplinary study carried out over 2 yr at the Great Barrier Reef, Australia (ENCORE: Hoegh-Guldberg et al. 1997, Ward \& Harrison 2000, Koop et al. 2001) did not reveal many of the detrimental effects on corals generally expected from nutrient enrichments (such as increased mortality and reduced reproduction and growth rates of corals). Increased concentration of nutrients had a number of conflicting effects on the organisms (corals, other reef invertebrates and algae) living within the ENCORE patch reefs. Nutrient types and concentrations may, therefore, dramatically influence the directionality of biological response in reef-dwelling organisms. In coral reefs subjected to numerous detrimental impacts (e.g. the coral reef of Eilat: Epstein et al. 1999, 2001) inflicted by large numbers of swimmers, snorkelers and SCUBA divers, various forms of anthropogenic pollution, siltation and sand deposition, etc., it is difficult to separate and quantify the relative contribution of each impact to reef decline. Therefore, our results challenge the prevailing notion among the general public (see http://ecesorg/articles/static/98679240033 115.shtml) that nutrient effluents released from intensive net-pen fish-farms in the Gulf of Eilat is the major detrimental factor contributing to the degradation of the coral reefs along the Israeli coast.

Acknowledgements. We wish to thank Timor Katz and Noa Eden for useful suggestions and assistance during various stages of the field work, the staff of Ardag fish farm, and Roni Dalal and the Inter-University Institute of Eilat for technical support. This study was partially supported by the Monitoring Program for the Jordanian-Israeli Peace Park in the Gulf of Eilat and by the AID-CDR.

\section{LITERATURE CITED}

Angel DL, Krost P, Gordin H (1995) Benthic implication of net cage aquaculture in the oligotrophic Gulf of Aqaba. Soc Spec Publ Eur Aquac 25:129-173

Anthony KRN (1999) Coral suspension feeding on fine particulate matter. J Exp Mar Biol Ecol 232:85-106

Anthony KRN, Fabricius KE (2000) Shifting roles of heterotrophy and autotrophy in coral energetics under varying turbidity. J Exp Mar Biol Ecol 252:221-253

Atkinson MJ, Carlson B, Crow GL (1995) Coral growth in high-nutrient, low $\mathrm{pH}$ seawater: a case study of corals cultured at the Waikiki Aquarium, Honolulu, Hawaii. Coral Reefs 14:215-223

Beveridge MCM (1996) Cage aquaculture, 2nd edn. Blackwell Fishing News Books, Oxford

Black KD (2001) Environmental impacts of aquaculture, Sheffield Academic Press, Sheffield

Brenner S, Berman T, Paldor N (2001) The observed circulation in the northern tip of the Gulf of Aqaba. Thirty-third Anniversary Conf Heinz Steinitz Mar Biol Lab, 21-24 October 2001, p 24-27
Brown JR, Gwen RJ, McLusky DS (1987) The effect of salmon fish farming on the benthos of a Scottish Sea loch. J Exp Mar Biol Ecol 109:35-51

Davies PS (1990) A rapid method for assessing growth rates of corals in relation to water pollution. Mar Pollut Bull 21: $346-348$

Davies PS (1995) Coral nubbins and explants for reef assessment and laboratory ecotoxicology. Coral Reefs 14: 267-269

D'Elia CF (1977) The uptake and release of dissolved phosphorus by reef corals. Limnol Oceanogr 22:301-315

Dubinsky Z, Stambler N (1996) Marine pollution and coral reefs. Glob Change Biol 2:511-526

Epstein N, Bak RPM, Rinkevich B (1999) Implementation of a small-scale 'no use zone' policy in a reef ecosystem: Eilat's reef lagoon six years later. Coral Reefs 18:327-332

Epstein N, Bak RPM, Rinkevich B (2001) Strategies for gardening denuded coral reef areas: the applicability of using different type of coral material for reef restoration. Restor Ecol 9:432-442

Ferrier-Pagès C, Guttuso JP, Dallot $S$, Jaubert J (2000) Effect of nutrient enrichment on growth and photosynthesis of the zooxanthellate coral Stylophora pistillata. Coral Reefs 19:103-113

Genin A, Lazar B, Brenner S (1995) Vertical mixing and coral death in the Red Sea following the eruption of Mount Pinatubo. Nature 377:507-510

Grigg RW (1995) Coral reefs in an urban enbayment on Hawaii: a complex case history controlled by natural and anthropogenic stress. Coral Reefs 14:253-266

Grover R, Maguer JF, Reynaud-Vaganay S, Ferrier-Pagès C (2002) Uptake of ammonium by scleractinian coral Stylophora pistillata: effect of feeding, light, and ammonium concentration. Limnol Oceanogr 47:782-790

Harriott VJ (1993) Coral lipids and environmental stress. Environ Monit Asses 25:131-139

Harrison P, Ward S (2001) Elevated levels of nitrogen and phosphorus reduce fertilisation success of gametes from scleractinian reef corals. Mar Biol 139:1057-1068

Hoegh-Guldberg O, Smith GJ (1989) Influence of the population density of zooxanthellae and supply of ammonium on the biomass and metabolic characteristics of the reef corals Seriatopora hystrix and Stylophora pistillata. Mar Ecol Prog Ser 57:173-186

Hoegh-Guldberg O, Takabayashi M, Moreno G (1997) The impact of long-term nutrient enrichment on coral calcification and growth. Proc 8th Int Coral Reef Symp, Panamá 1: 861-866

Hunter CL, Evans CW (1995) Coral reefs in Kaneohe Bay, Hawaii: two centuries of western influence and two decades of data. Bull Mar Sci 57:501-515

Karakassis I (2001) Ecological effects of fish farming in the Mediterranean. In: Environmental impact assessment of Mediterranean aquaculture farms. Cah Options Méditerr p 15-22

Katz T, Herut B, Genin A, Angel DL (2002) Grey mullets ameliorate organically enriched sediments below a fish farm in the oligotrophic Gulf of Aqaba (Red Sea). Mar Ecol Prog Ser 234:205-214

Kinsey DW, Davies PJ (1979) Effects of elevated nitrogen and phosphorus on coral reef growth. Limnol Oceanogr 24:935-940

Koop K, Booth D, Broadbent A, Brodie J and 16 others (2001) ENCORE: the effect of nutrient enrichment on coral reefs: synthesis of results and conclusions. Mar Pollut Bull 42: 91-120

Lapoint BE (1997) Nutrient thresholds for bottom-up control 
of macroalgal blooms on coral reefs in Jamaica and southeast Florida. Limnol Oceanogr 42:1119-1131

Lieberman T, Genin A, Loya Y (1995) Effects on growth and reproduction of the coral Stylophora pistillata by the mutualistic damselfish Dascyllus marginatus. Mar Biol 121:741-746

Loya Y (1972) Community structure and species diversity of hermatypic corals at Eilat, Red Sea. Mar Biol 13:100-123

Loya Y (1976) The Red Sea coral Stylophora pistillata is an $r$ strategist. Nature 259:478-480

Lupatsch I, Kissil GW (1998) Predicting aquaculture waste from gilthead seabream (Sparus aurata) culture using a nutritional approach. Aquat Living Resour 11:265-268

Mancy KH (1993) Gulf of Aqaba ecological overview and call to action. In: Sandler D, Adly E, Al-Kushman MA (eds) Protecting the Gulf of Aqaba: a regional environmental challenge. Envezonntae Law Institute, Washington, DC, p 19-24

Marubini F, Atkinson MJ (1999) Effects of lowered pH and elevated nitrate on coral calcification. Mar Ecol Prog Ser 188:117-121

Meyer JL, Shultz ET (1985a) Migrating haemulid fishes as a source of nutrients and organic matter on coral reefs. Limnol Oceanogr 30:146-156

Meyer JL, Shultz ET (1985b) Tissue condition and growth rate of corals associated with schooling fish. Limnol Oceanogr 30:157-166

Muller-Parker G, McCloskey LR, Hoegh-Guldberg O, McAuley PJ (1994) Effect of ammonium enrichment on animal and algal biomass of the coral Pocillopora damicornis. Pac Sci 48:273-283

Muscatine L, D'Elia CF (1978) The uptake, retention, and release of ammonium by reef corals. Limnol Oceanogr 23: $725-734$

Naim O (1993) Seasonal responses of a fringing reef community to eutrophication (Reunion Island, Western Indian Ocean). Mar Ecol Prog Ser 99:137-151

Pastorok RA, Bilyard GR (1985) Effects of sewage pollution on coral-reef communities. Mar Ecol Prog Ser 21:175-189

Pitta P, Karakassis I, Tsapakis M, Zivanovic S (1999) Natural vs. mariculture induced variability in nutrients and plankton in the eastern Mediterranean. Hydrobiologia 391:181-194

Rinkevich B (1996) Do reproduction and regeneration in damaged corals compete for energy allocation? Mar Ecol Prog Ser 143:297-302

Rinkevich B, Loya Y (1979) The reproduction of the Red Sea coral Stylophora pistillata. I. Gonads and planulae. Mar Ecol Prog Ser 1:133-144

Rinkevich B, Loya Y (1983) Short term fate photosynthetic products in a hermatypic coral. J Exp Mar Biol Ecol 73: $175-184$

Editorial responsibility: Otto Kinne (Editor),

Oldendorf/Luhe, Germany
Roberts CM, McClean CJ, Veron JEN, Hawkins JP and 8 others (2002) Marine biodiversity hotspots and conservation priorities for tropical reefs. Science 295:1280-1284

SAS Institute (1999) Statistical Analysis System, SAS/STAT, User's Guide Version 8. SAS, Cary, NC

Shafir S, Van Rijn J, Rinkevich B (2001) Nubbing of coral colonies: a novel approach for the development of inland broodstocks. Aquat Sci Conserv 3:183-190

Smith SV, Kimmerer WJ, Laws EA, Brock RE, Walsh TW (1981) Kane'ohe Bay sewage diversion experiment: perspectives on ecosystem responses to nutritional perturbation. Pac Sci 35:279-395

Snidvongs A, Kinzie RA III (1994) Effects of nitrogen and phosphorus enrichment on in vivo symbiotic zooxanthellae of Pocillopora damicornis. Mar Biol 118:705-711

SPSS (1989-1997) Subprograms of the statistical package for the social sciences, SPSS 11, available at: www.spss.com. McGraw Hill, New York

Stambler N, Popper N, Dubinsky Z, Stimson J (1991) Effects of nutrient enrichment and water motion on the coral Pocillopora damicornis. Pac Sci 45:299-307

Stambler N, Cox EF, Vago R (1994) Effect of ammonium enrichment on respiration, zooxanthellae densities and pigment concentrations in two species of Hawaiian corals. Pac Sci 48:284-290

Steven ADL, Broadbent AD (1997) Growth and metabolic responses of Acropora palifera to long term nutrient enrichment. Proc 8th Int Coral Reef Symp 1:867-872

Stimson J (1992) The effect of ammonium addition on coral growth rate. Proc 7 th Int Coral Reef Symp, Mangilao $1: 383$

Tomascik T (1990) Growth rates of two morphotypes of Montastraea annularis along an eutrophication gradient, Barbados WI. Mar Pollut Bull 21:376-381

Tomascik T, Sander F (1985) Effect of eutrophication on reefbuilding corals. I. Growth rate of the reef-building coral Montastraea annularis. Mar Biol 87:143-155

Tomascik T, Sander F (1987) Effect of eutrophication on reefbuilding corals. Mar Biol 94:77-94

Wallace CC (1999) Staghorn corals of the world. CSIRO Australia, East Melbourne

Ward S, Harrison P (2000) Changes in gametogenesis and fecundity of acroporid corals that were exposed to elevated nitrogen and phosphorus during the ENCORE experiment. J Exp Mar Biol Ecol 246:179-221

Wittenberg M, Hunte W (1992) Effects of eutrophication and sedimentation on juvenile corals I. Abundance, mortality and community structure. Mar Biol 112:131-138

Yahel G, Post AF, Fabricius K, Marie D, Vaulot D, Genin A (1998) Phytoplankton distribution and grazing near coral reefs. Limnol Oceanogr 43:551-563

Submitted: September 4, 2002; Accepted: December 12, 2002 Proofs received from author(s): April 22, 2003 